\section{Development of Employment Sub-centres in the City of Ahmedabad, India}

\author{
Talat Munshi' \\ Mark Brussel ${ }^{2}$ \\ Mark Zuidgeest ${ }^{3}$ \\ Martin Van Maarseveen ${ }^{2}$
}

Environment and Urbanization ASIA

9(I) 37-5I

(C) 2018 National Institute of Urban Affairs (NIUA)

SAGE Publications

sagepub.in/home.nav

DOI: I0.I I77/09754253 I774852 I

http://journals.sagepub.com/home/eua

\begin{abstract}
This article describes how employment sub-centres can be identified applying geo-spatial modelling techniques in the context of metropolitan areas in India, and how the development of these employment centres can be linked to the levels of accessibility to labour, access to transport infrastructure as well as land use mix and land use diversity. For the city of Ahmedabad, employment sub-centres are identified for the year 2010, while the progression of employment in retail, commercial and industrial sectors in each of these centres is studied for the period from 1980 to 2010. Definite the signs of sprawl-type development and polarization reversal are observed, including the emergence of new employment sub-centres across the urban area, and the rapid growth of centres further away from the central business district. Retail and commercial sectors have grown exponentially, whereas industrial and manufacturing sector's growth is stagnant. This development is mixed and heterogeneous, with the growth of the retail and the commercial sectors found to have a significant and positive relation with access to labour and transport infrastructure. These identified patterns of development provide important information to urban planners enabling them to make informed decision, for example, in locating future employment activities, identifying future transit-oriented development nodes, etc.
\end{abstract}

\title{
Keywords
}

GIS, employment sub-centres, accessibility, land use, Spatial autocorrelation

\footnotetext{
' DTU_Department of Management Engineering, UN City, Copenhagen, Denmark.

${ }^{2}$ Faculty of Geo-Information Science and Earth Observation, University of Twente, The Netherlands.

${ }^{3}$ Centre for Transport Studies, Department of Civil Engineering, Faculty of Engineering and the Built Environment, University of Cape Town, South Africa.
} 
Environment and Urbanization ASIA 9(I)

\section{Introduction}

Studies have noted changing urban and metropolitan structure, spatial expansion of built-up area, the dispersal of economic activities and the emergence of polycentric structures (Chattopadhyay, 2017; Mahadevia, 2001; Munshi, 2013; Roy, 2009). What is not very clear is the precise definition and the determinants of growth in these urban centres (employment sub-centres). Urban planners prepare statuary urban development plans to accommodate urban growth, provide housing and other infrastructure to support urban growth and ensure sustained growth of cities. However, the planning methods and tools used to prepare statutory urban development plans in India have been criticized as being ineffective (Munshi, 2013; Munshi, Zuidgeest, Brussel, \& Van Maarseveen, 2014b), while regulators have only a partial control on the development a large portion of the land use development is of laissez-faire type (Ballaney \& Patel, 2008; Ilhamdaniah, Munshi, \& Amer, 2005; Munshi et al., 2014b). One can assume that the development of employment sub-centres outside the central core area is more organic development and less planned.

This laissez-faire type of distribution of land uses and the emergence of employment sub-centres outside the city core itself can provide key inputs as to how and where land uses develop and can serve as precursors on how to go about planning cities. With the recent focus on developing nodes around transit lines and stops, research on how activities cluster can provide key inputs to urban planners. Typically, firms and establishments cluster at central locations (Christaller, 1966; Hotelling, 1929) to gain benefits resulting from production optimization, innovation and business opportunities (Porter, 2000), usually termed as central business district (CBD). As demand to locate centrally is high, the cost of locating centrally is also high. By relocating away from the CBD, firms can typically optimize their cost of production (Fujita, Krugman, \& Venables, 2001), also referred to as polarization reversal (Richardson, 1980). As such, modern metropolitan areas are not always monocentric and may have a number of sub-centres that rival the CBD location. In conventional literature, this phenomenon is already widely discussed (Anas, Arnott, \& Small, 1998; Hall \& Pain, 2006; Kloosterman \& Lambregts, 2001; Meijers, 2005). Development of employment sub-centres in most cities reflects the rise in service economy and also indicates increased autonomy of sub-areas within the city from the CBD area (Romein, Verkoren, \& Fernandez, 2009). Linkages with transport and customer/labour/goods leading to, for example, commuter flows, are important drivers of polycentric development (Giuliano, Redfearn, Agarwal, \& $\mathrm{He}, 2012)$. Moreover, as stated earlier, there can be a tendency to locate centrally, so distance from the city centre can influence locations where economic activity clusters' develop.

Indian cities are different from cities in the Western countries, where the aforementioned theories were developed and tested. As cited in the case of Ahmedabad and Rajkot (Munshi, Belal, \& Dijst, 2004; Munshi et al., 2014a; Munshi et al., 2014b), activities show a tendency to locate close to the centre of the town in Indian cities as well. Accessibility to other activities (including residential) has a positive influence on activity location, indicating a tendency for activities to cluster and locate in proximity to each other. Cities are dense and heterogeneous; they are also likely to be less service oriented, while affordability of transport costs to most residents is also limited. This makes it interesting to explore the formation of employment sub-centres and attribute reasons to it, which is the main objective of this article. Therefore, in this research, the emergence of employment sub-centres outside the CBD is identified. The growth of retail, office and industrial floor space within these identified centres is studied with respect to their proximity to the number of resident workers, distance from city centre and the configuration of the transport network and land use. The case study city of Ahmedabad is located in the state of Gujarat in western India (Figure 1). Ahmedabad is considered a typical city that is classified in the second tier of cities in India as it is confronted with rapid urban growth and related urban problems typical to most Indian cities. 


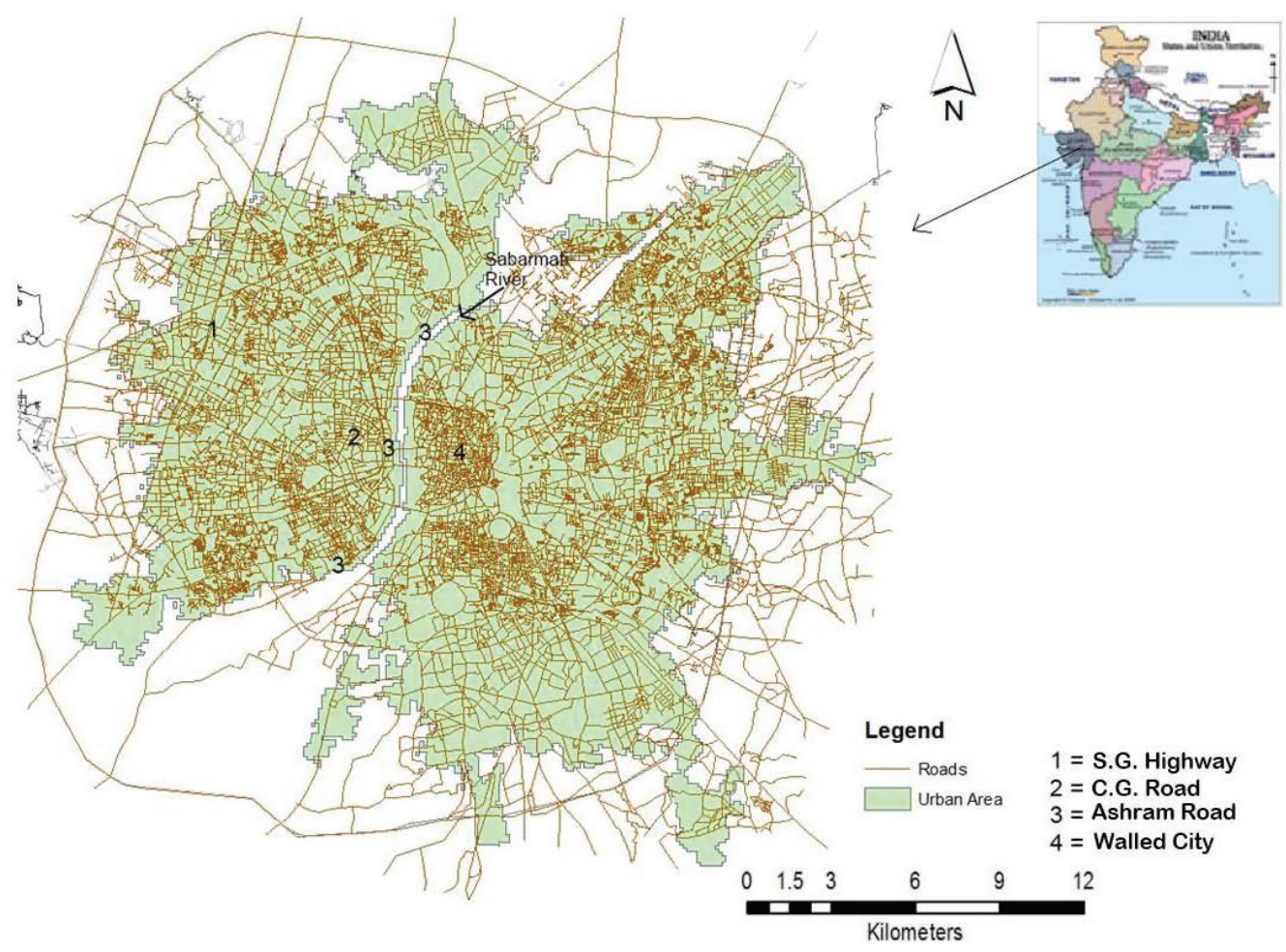

Figure I. Ahmedabad City Location'

Source: Inset image (https://www.mapsofindia.com/maps/india/india-political-map.htm)

This article is further organized in two main sections followed by conclusion and discussion. In the further sections, the concepts and methods for identifying sub-centres using GIS are discussed. Next, the employment sub-centres for Ahmedabad are identified and characterized, and a change in topology of employment and its relation with access to labour, distance from city and configuration of transport network and land use is discussed. Finally, the last section draws conclusions and presents recommendations for further research.

\section{Research Approach, Methodology and Data}

Giuliano and Small's (1991, 1999) and many other empirical research (Anderson \& Bogart, 2001; Bogart \& Ferry, 1999; McMillen \& McDonald, 1997; Shearmur \& Coffey, 2002; Small \& Song, 1994) identify employment sub-centres as locations that form a continuous cluster with a cut-off for employment density and a minimum total employment. The cut-off point of gross employment density used is 10 jobs per acre (25 jobs per hectare) in Giuliano and Small (1991), while other studies have used slightly different cut-off densities, for example, Small and Song (1994) use cut-off job density as 37 jobs per hectare and Anderson and Bogart (2001) use cut-off job density as 20 jobs per hectare. The total minimum employment 
Environment and Urbanization ASIA 9(I)

in the identified continuous cluster is between 5,000-10,000 jobs (Giuliano \& Small, 1991) and 35,000 (Small \& Song, 1994). Shearmur and Coffey (2002) also used employment to residents ratio (greater than one) to identify the continuous clusters of employment. Other methods use a two-stage nonparametric approach to identifying employment clusters (McMillen, 2001; McMillen \& Smith, 2003; Redfearn, 2007). In Redfearn (2007), a local weighted regression curve (Loess curve) is used to generate an employment density surface, from which employment sub-centres are identified. An employment sub-centre is identified as a location having substantially higher employment density compared to its neighbouring area. A similar approach includes the estimation of spline functions (Craig \& $\mathrm{Ng}, 2001$; Muniz, Galindo, \& Garcia, 2003), which is a non-parametric specification of a density function, an approach that is similar to the boundary definition procedure used in Redfearn (2007). McMillen (2001) identifies sub-centres using the properties of a contiguity matrix. This method uses the residues of an econometric estimation of the density function (parametric or non-parametric). The residues that are statistically diverse from zero are considered as so-called candidate sub-centres.

In this study, employment sub-centres are identified using a $100 \mathrm{~m}$ equal side grid to quantify the various data. Data on the distribution of commercial, retail, industrial and residential floor space were available from Munshi (2013). The data on the total workers in different categories are available from the Census 2001 and 2011, and are used to disaggregate jobs to each grid cell using proportion of the area under each activity in the cell. Subsequently, the following steps were followed to identify employment sub-centres:

1. A topological surface of employment densities is created

2. From the employment density surface, all local maxima are identified and considered as candidate employment centres

3. Contiguous grid cells around the local maxima that have more than a minimum qualifying threshold of 10 jobs/acre are selected to form a cluster

4. For each cluster, all grid cells in the clusters plus other grid cells in the neighbourhood (equal to the number of grid cells in the employment sub-centre) are selected

5. A non-parametric Loess surface is created using the methods described in Redfearn (2007)

6. For the Loess surface, the following definition of an employment sub-centre by Redfearn (2007) has been used: all the contiguous cells that have values higher than the mean minus half standard deviation (of all the Loess surface values) are selected and considered as an employment subcentre within the city.

As an example, in Figure 2, a representation of the methods used to identify the Employment Sub-centre No. 10 is shown. Locations with values higher than 10 jobs/acre are identified as potential areas for employment sub-centre in Step 1, one of these centres being Cadilla area. These locations, as identified in Step 1, are then deducted from the rest of the city area. In this remaining surface, the non-parametric density value of 93 (mean (39) + half standard deviation (108)) is used as the cut-off value to identify the location of the sub-centre. The resultant area is finally identified as the employment sub-centre no 10 , which was confirmed by local knowledge of the area. This procedure is used to identify 28 employment sub-centres next to the existing CBD city centre. In Figure 3, these centres are also ranked in the order of employment numbers. The river Sabarmati appears to act as a barrier to the traditional CBD ( 1 in Figure 3) for the residents living west to the river. This has led to the creation of a large employment sub-centre in the western part of the city mirroring the traditional CBD. Other smaller employment subcentres have also emerged on both sides of the river.

Accessibility can be defined as the 'ease of reaching opportunities', and is concerned with increasing the ability with which people in different locations, and with differing availability of transport, can reach different services or opportunities, such as employment, shopping and leisure (Stantchev \& Merat, 2010). 

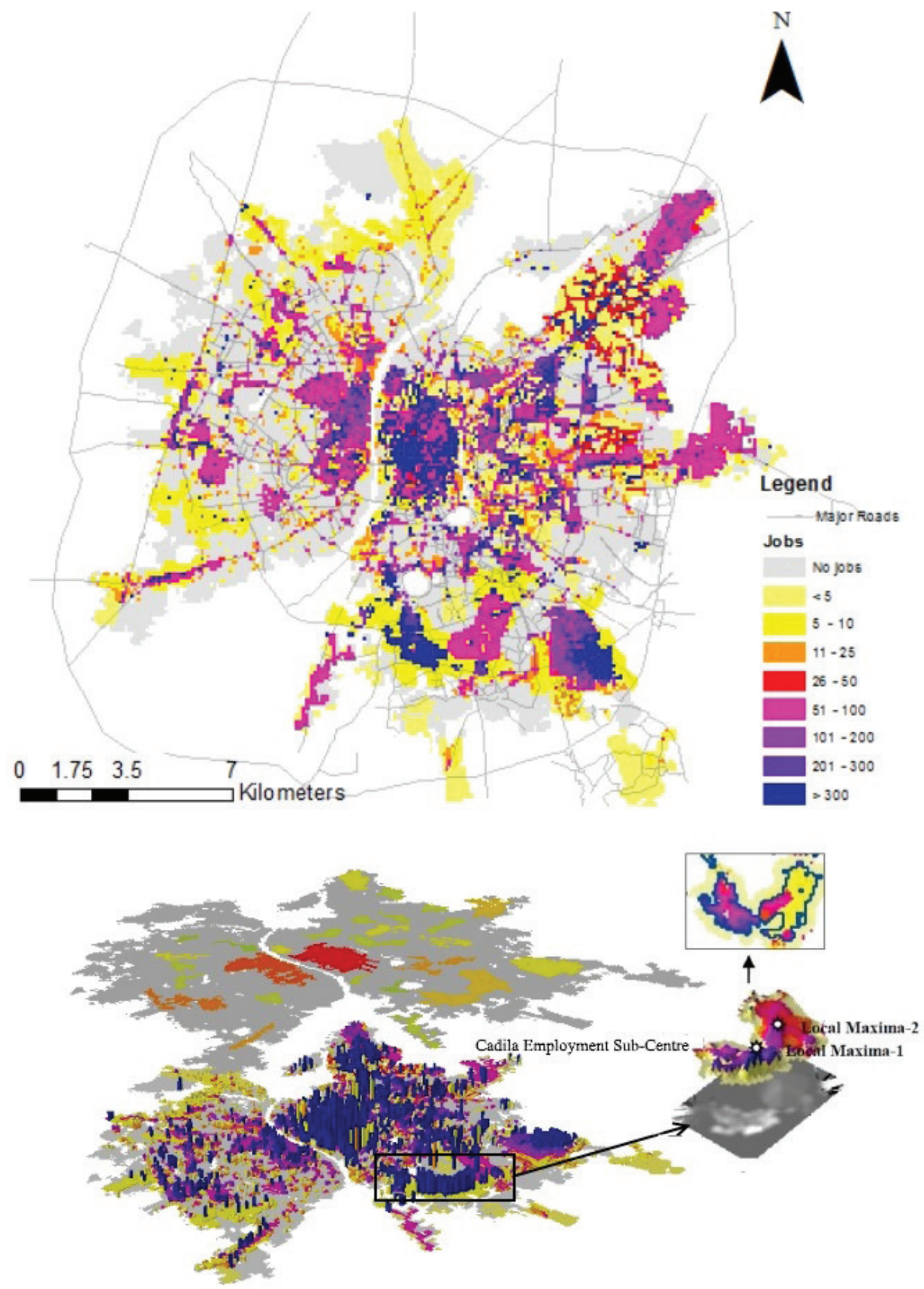

Digital Elevation Surface of Employment Density and Identification of Cadilla Employment Sub-Centre

Figure 2. Topology of Jobs and Identification of Employment Sub-centres in Ahmedabad'

Source: Study Results. 


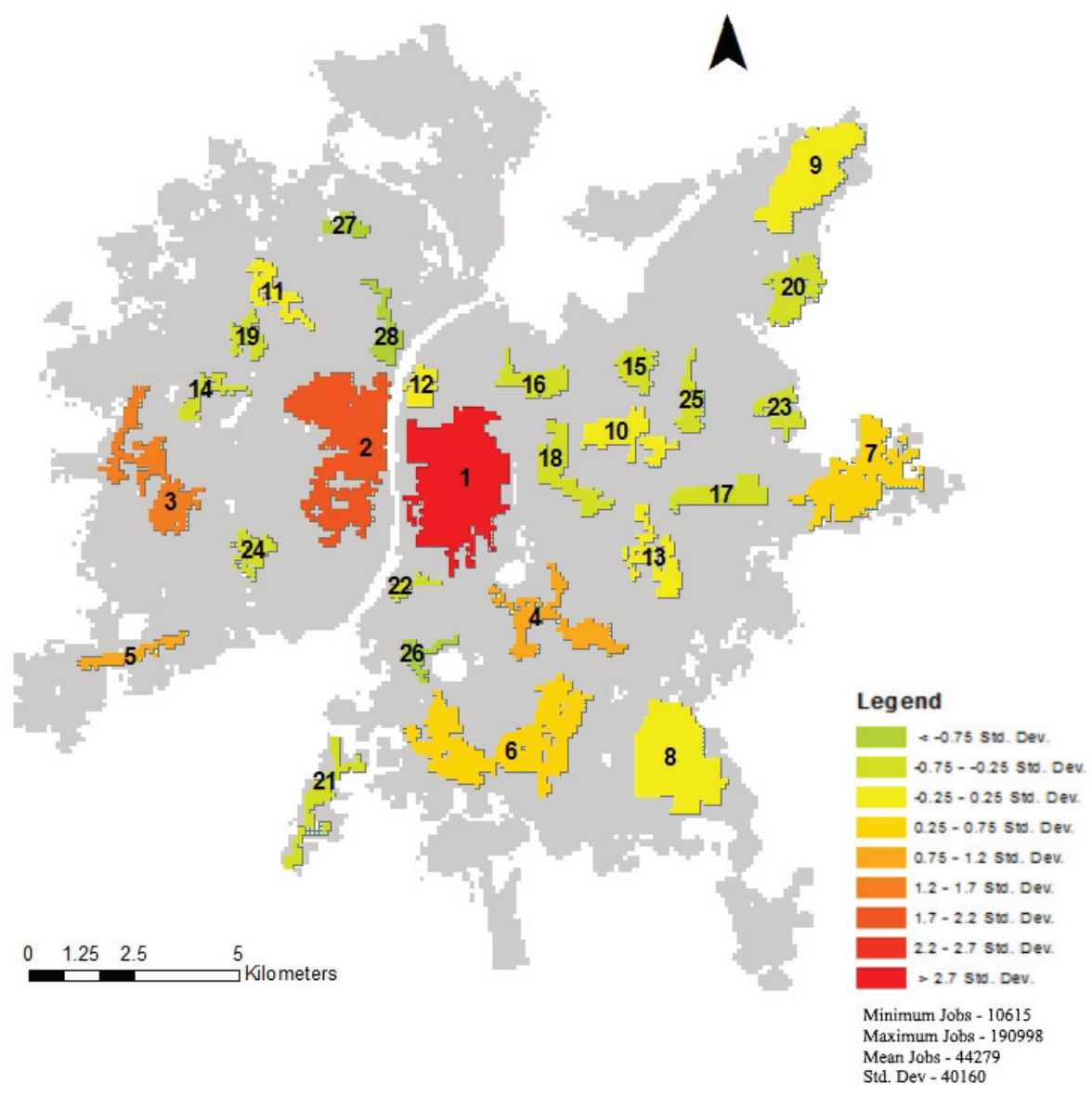

Figure 3. Identified Employment Sub-centres'

Source: Study Results.

The development potential of a location (and thereby land prices) has a strong correlation with accessibility (partly a function of transport mobility) (Giuliano et al., 2012). The transport cost, representing individual's reluctance to travel in many ways effects spreading and clustering of economic activities (Brotchie, 1984). For the development of economic activities, they need access to transport networks, access to transport nodes and access to labour force. The accessibility to labour is computed as access to individuals (residential workers) from a given location. The data on numbers of residential workers was available from Census data 2001 and 2011, and was available at the census ward level, dissaggregated to grids of $100 \mathrm{~m}$ using residential building floor space as a distribution function. The accessibility to labour is operationalized as in Equation 1.

$$
a_{i}=\frac{1}{\sum_{j=1}^{n} L F\left(d_{i j}\right)}
$$


where $a_{i}$ (used as the balancing factor in the gravity model) is a measure of accessibility at the employment sub-centre $i$ to the availability of labour $L, F\left(d_{i j}\right)$ is a function of $d_{i j}$ for which, in this case, the exponential function is used. The variable $d_{i j}$ is the distance between $i$ and $j$. Accessibility values are accordingly normalized between 0 and 100 .

Data on the road network was sourced from Munshi (2003) and updated using Cartosat image data from 2007 and by using Google Maps data for 2011. To compute accessibility to roads and public transport, a Kernel density function is used, which is based on Tracy, Su, Sadek and Wang (2011). Access to major roads is computed using Kernel density function, using road width as the population field ${ }^{2}$ and accessibility to public transport computed as kernel density of public transport stops, using the number of routes as population field. ${ }^{3}$ Distance from the city centre provide inputs on how proximity to the centre influences employment growth, which is computed as network distance from the centre of Nehru Bridge to the centre of employment sub-centre.

Land use mix and diversity can, first of all, indicate whether the employment sub-centre emerge as exclusive employment zones, and second, provide inputs to the development potential of employment if the location are mixed with residential and other land uses. The land use mix and diversity is quantified by adapting land use extropy and land use diverstiy indicators from Cervero and Kockelman (1997). Entropy Index and Dissimilarity Index are quantified as shown in Equations 2 and 3.

$$
\text { Entropy Index }=E_{i}=\sum_{j} \frac{F_{j} \times \ln \left(F_{j}\right)}{\ln (J)}
$$

where $J$ is the number of land use classes (five land use classes have been considered in this study: residential, commercial, institutional, industrial and recreational), $F_{j}$ is the proportion of the total developed floor space area under the $j$ th land use type. An area within a radius of $800 \mathrm{~m}$. (8 grid cells) is considered as the neighbourhood.

$$
\text { Dissimilarity Index }=\sum_{j}^{k} \sum_{i}^{8}\left(\frac{X_{i}}{8}\right) / K
$$

where $K$ is the number of actively developed floor space in a grid cell and $X_{i}=1$, if central active floor space use type differs from that of neighbouring grid cell.

The relation between the growth of employment within the identified employment centres and accessibility to labour, accessibility to transport, land use mixing and distance from city centre is studied using the spatial autocorrelation Moran's I statistic (Anselin, Syabri, \& Kho, 2006). LISA significance maps (Anselin et al., 2006) are also used, as these maps depict the locations with significant Local Moran statistics and classify those locations by type of association.

\section{Results}

The inventory of identified employment sub-centres is studied for growth in the number of jobs for four time periods: 1980, 1990, 2000 and 2010. Table 1 shows the distribution of jobs and their growth in the last three decades. Age of the building ${ }^{4}$ is used to compute the values in the table. It is found that the primacy of the CBD (Employment Centre 1) has steadily decreased over the last three decades. In 1980, close to a quarter of the total employed in Ahmedabad worked in the CBD area, whereas other employment centres were either industrial areas or the area adjacent to the city centre on the other side of the river. The number of employment sub-centres with more than 10,000 jobs has also increased from 
Table I. Employment Sub-centre and Growth in Number of Jobs

\begin{tabular}{|c|c|c|c|c|c|c|c|c|}
\hline \multirow[b]{2}{*}{$\begin{array}{l}\text { Emploment } \\
\text { Sub Centre }\end{array}$} & \multicolumn{2}{|c|}{1980} & \multicolumn{2}{|c|}{1990} & \multicolumn{2}{|c|}{2000} & \multicolumn{2}{|c|}{2010} \\
\hline & Jobs & $\begin{array}{c}\% \text { of } \\
\text { Total Jobs }\end{array}$ & Jobs & $\begin{array}{c}\% \text { of } \\
\text { Total Jobs }\end{array}$ & Jobs & $\begin{array}{c}\% \text { of } \\
\text { Total Jobs }\end{array}$ & Jobs & $\begin{array}{c}\% \text { of } \\
\text { Total Jobs }\end{array}$ \\
\hline 1 & 83200 & 23 & 95776 & 17 & $1485 \mid 3$ & 12 & 190998 & 11 \\
\hline 2 & 23436 & 7 & 33490 & 6 & 92093 & 8 & 123277 & 7 \\
\hline 3 & 1151 & 0 & 5148 & I & 84697 & 7 & 109879 & 6 \\
\hline 4 & 29782 & 8 & 43467 & 8 & 67423 & 5 & 86094 & 5 \\
\hline 5 & 1185 & 0 & 2335 & 0 & 46384 & 4 & 77453 & 4 \\
\hline 6 & 29453 & 8 & 41966 & 7 & 55004 & 4 & 65548 & 4 \\
\hline 7 & 13532 & 4 & 20386 & 4 & 41285 & 3 & 55303 & 3 \\
\hline 8 & 11684 & 3 & 23181 & 4 & 31185 & 3 & 40850 & 2 \\
\hline 9 & 6645 & 2 & $|165|$ & 2 & 27312 & 2 & 39151 & 2 \\
\hline 10 & 6345 & 2 & 15473 & 3 & 29456 & 2 & 38993 & 2 \\
\hline 11 & 2062 & I & 5194 & I & 26373 & 2 & 38676 & 2 \\
\hline 12 & 23022 & 6 & 26499 & 5 & 32529 & 3 & 36408 & 2 \\
\hline 13 & 10910 & 3 & 15806 & 3 & 30365 & 2 & 34839 & 2 \\
\hline 14 & 1437 & 0 & 3647 & I & 27805 & 2 & 32288 & 2 \\
\hline 15 & 10015 & 3 & 16456 & 3 & 24844 & 2 & 28450 & 2 \\
\hline 16 & 3838 & 1 & 5483 & I & 20252 & 2 & 27534 & 2 \\
\hline 17 & 5961 & 2 & 15367 & 3 & 24265 & 2 & 27379 & 2 \\
\hline 18 & 11647 & 3 & 16546 & 3 & 22782 & 2 & 26393 & I \\
\hline 19 & 3790 & I & 3807 & I & 16581 & I & 23913 & I \\
\hline 20 & 9767 & 3 & 11553 & 2 & 17590 & I & 20921 & I \\
\hline 21 & 1130 & 0 & 8165 & I & 15170 & I & 17974 & 1 \\
\hline 22 & 7380 & 2 & 9991 & 2 & 15980 & I & 17155 & I \\
\hline 23 & 1742 & 0 & 3586 & 1 & | 4077 & I & 16186 & I \\
\hline 24 & 729 & 0 & 2313 & 0 & 11001 & I & | 4878 & I \\
\hline 25 & 2445 & 1 & 4230 & I & 11716 & I & | 4672 & I \\
\hline 26 & 4298 & 1 & 6958 & I & 9126 & I & 12777 & I \\
\hline 27 & 833 & 0 & 1350 & 0 & 6692 & I & 11218 & I \\
\hline 28 & 1813 & 1 & 2893 & I & 6995 & I & 10615 & 1 \\
\hline Other areas & 46207 & 13 & 113179 & 20 & 270063 & 22 & 531352 & 30 \\
\hline
\end{tabular}

Source: Study results.

9 (this excludes the CBD) in 1980 to 13 in 1990, to 24 in 2000 and 27 in 2010. The total employment contained within identified employment sub-centres was 83 per cent in 1980, while it has reduced to 69 per cent in 2010, despite increase in the number of employment sub-centres. The development of many employment sub-centres with a small number of jobs and the reduction in overall employment in these sub-centres indicates sprawl type of development. The urban form in the 1980 represents a city, 
where activities has just started to sprawl beyond the CBD area, mainly under the pressure of rural-urban migration and rapid population growth. In the 1990s, the Indian economy was liberalized, during this period, the growth of jobs in cities like Ahmedabad outpaced the formal land use formation. There was rampant conversion of land use from residential land use areas to retail and commercial uses and the development of spontaneous retail and commercial areas in peripheral areas leading to a spur in the number of employment centres from 13 to 24. In the years between 2000 and 2010, employment consolidated further in peripheral areas and also in the infill areas.

It is also obvious that reverse polarization is taking place and development is moving towards the peripheral locations. The spatial distribution and growth of the retail, commercial and industrial jobs in the past four decades within the identified employment sub-centres are shown in Figure 4. Industrial floor space includes small-scale factory production, printing industry, metal and all other allied activities that use floor space for production purpose including in the food industry. Overall, the industrial sector has not grown as fast as other sectors when we look at both the employment number (Table 1) and development of floor space. There are still a significant number of industrial establishment that are more than 30 years old, which are mainly located in and around the walled city area in the in select industrial zones in the eastern part of the city. The development has progressively moved towards the periphery over the years, with most of the recent industrial development concentrated along the four industrial centres towards the eastern periphery of the city. Retail floor space has grown exponentially in the last 20 years. The CG road (Employment Sub-centre 2) and SG highway (Employment Subcentre 3 ) (see Figures 1 and 3 ) are where most retail development has taken place, and where the presence of good road infrastructure in these area has clearly contributed to the emergence of large shopping complexes in these areas. Thus, a majority of retail floor space is concentrated with three major centres but statistical values presented in Figure 4 suggest, as one can expect, retail land use well distributed among all centres. In addition to the formal retail, which is captured in the numbers presented in Figure 4 and Table 1, a significant proportion of retail activities are informal development and street-side activities, as these have come along transport nodes and major node across the city. This study does not incorporate these developments, but these activities can be expected to pattern the formal land use development. Office floor space more or less patterns the retail floor space development and a large number of recent floor space development has taken place in the western part of the town, mainly near the SG highway city centre.

Descriptive statistics of quantified indicators are presented in Figure 5 and Table 2. Clearly, a pattern does emerge. Central portions as expected have better access to labour, transport and also have mixed and diverse land use. Most public transport bus routes (only AMTS bus routes considered and BRTS only started operation in 2009) are also located in and around the wall city area.

The spatial co-relation of the land use growth with the indicators described in the second section are now studied by computing the Moran's I value as described in Munshi (2016). The LISA cluster maps and Moran's I spatial autocorrelation values are presented in Figure 5. Positive Moran's $I$ value indicates positive relation likewise negative value indicates a negative relation. LISA significance maps also indicate the locations where the significance of these relations are high. The Moran's $I$ values for access to labour is positive and comparatively higher for retail development and commercial development and the significance of the relation is very high in several portions of the town, mainly along the western periphery, and employment sub-centres abutting the CBD. The new areas where activities have located in the past 30 years are location where residential development has taken place as well as location where space for development is available. The Moran's $I$ value of the relation between retail, office and industrial development with distance to the centre of the town also further explains this, positive and high Moran's $I$ value and high level of significance indicates that activities, especially retail and commercial activities, located away from city centre have a clear indication of polarization reversal. New activities have developed 


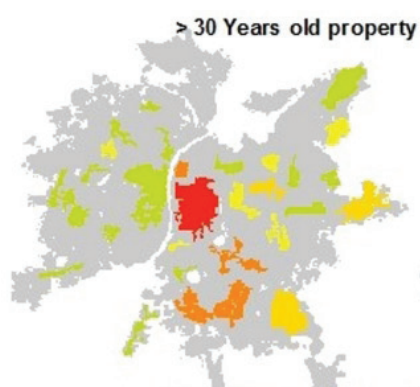

20 - 30 Years old property

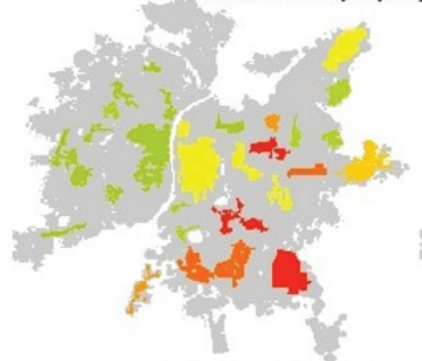

10-20 Years old property

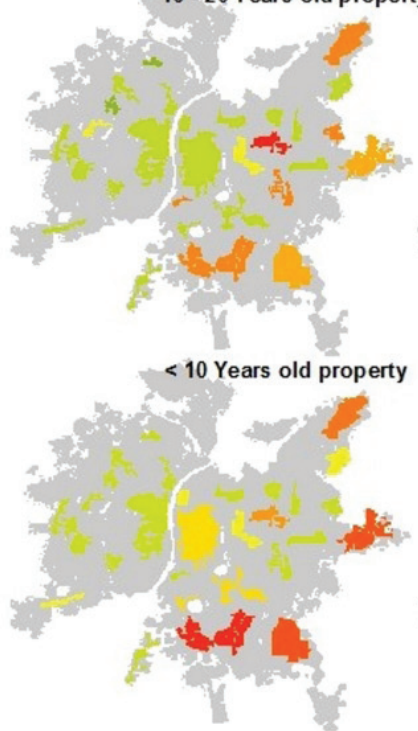

Industrial Floor Space

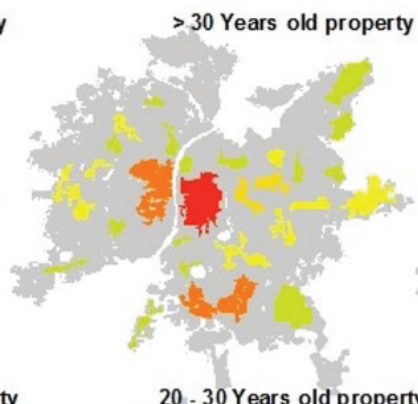

$20-30$ Years old property

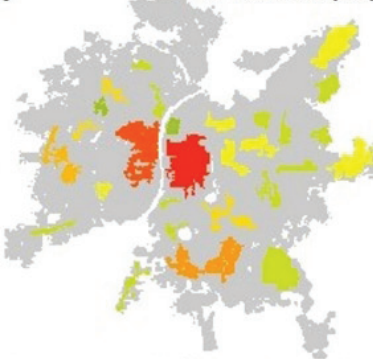

10 - 20 Years old property

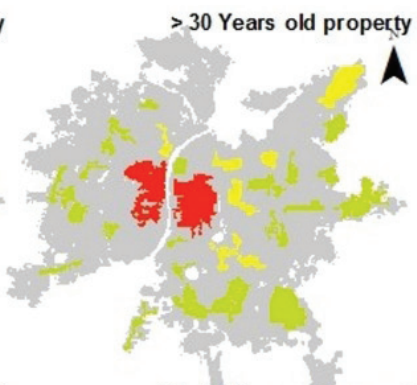

20- 30 Years old property

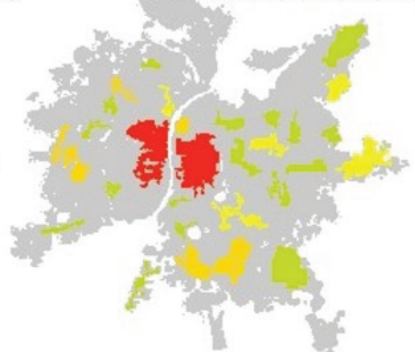

10. 20 Years old property
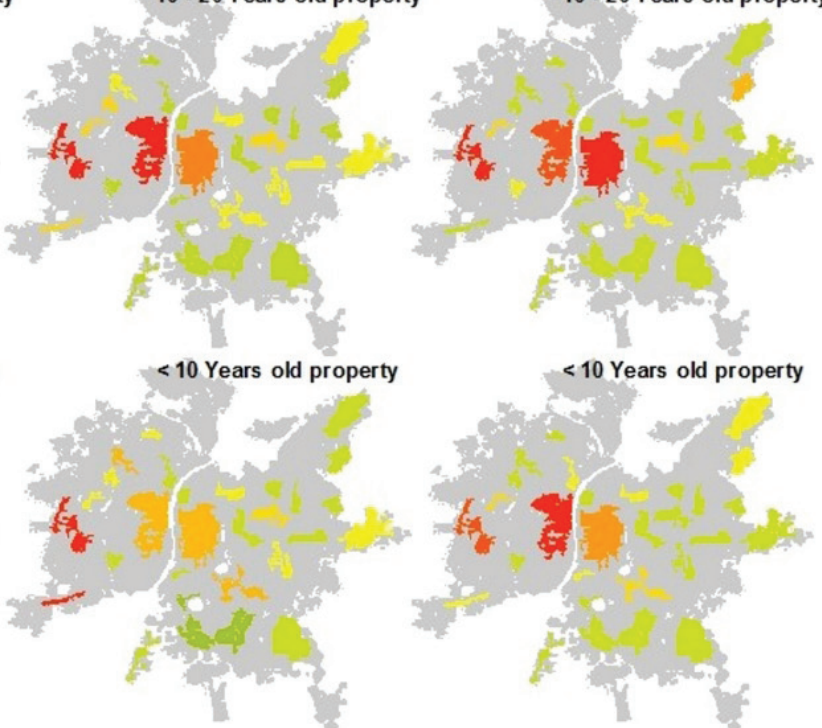

Retail Floor Space

$<10$ Years old property

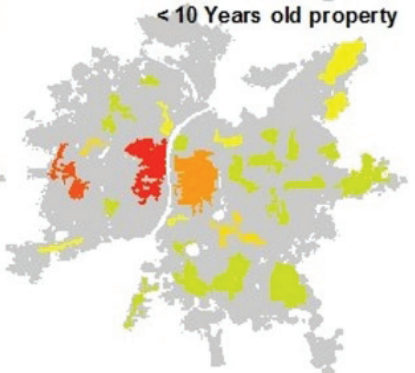

Office Floor Space

Legend

\begin{tabular}{|c|c|c|c|c|c|c|c|c|c|c|c|c|c|}
\hline \multirow{2}{*}{ 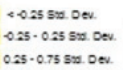 } & \multicolumn{13}{|c|}{ Data Values } \\
\hline & 5tatistics & \multicolumn{4}{|c|}{ Industrall floor 5 pace/ Age of Property } & \multicolumn{4}{|c|}{ Retallfloor Space/ Age of Property } & \multicolumn{4}{|c|}{ Office Floor Space/ Age of Property } \\
\hline $0.75 \cdot 1.2530 .000$. & Min & 0 & o & o & 0 & o & 456 & 670 & 1500 & o & of & of & 0 \\
\hline $1.7 \cdot 22530.0 \mathrm{ev}$. & Mean & 81104 & 33233 & 17646 & 17268 & 23099 & 25223 & 68011 & 91751 & 31057 & 8407 & 7571 & 18164 \\
\hline 22.27530 .000 & Median & 48695 & 21550 & 7929 & 6439 & 13285 & 13241 & 34656 & 47306 & 3964 & 2415 & 2445 & 8222 \\
\hline$>27$ smo Dev & STDEV & 107658 & 35434 & 20613 & 22865 & 31653 & 29924 & 111120 & 136372 & 91494 & 15517 & 12797 & 29752 \\
\hline
\end{tabular}

Figure 4. Employment Sub-centre and Development of Industrial, Retail and Office Floor Space' Source: Study Results. 


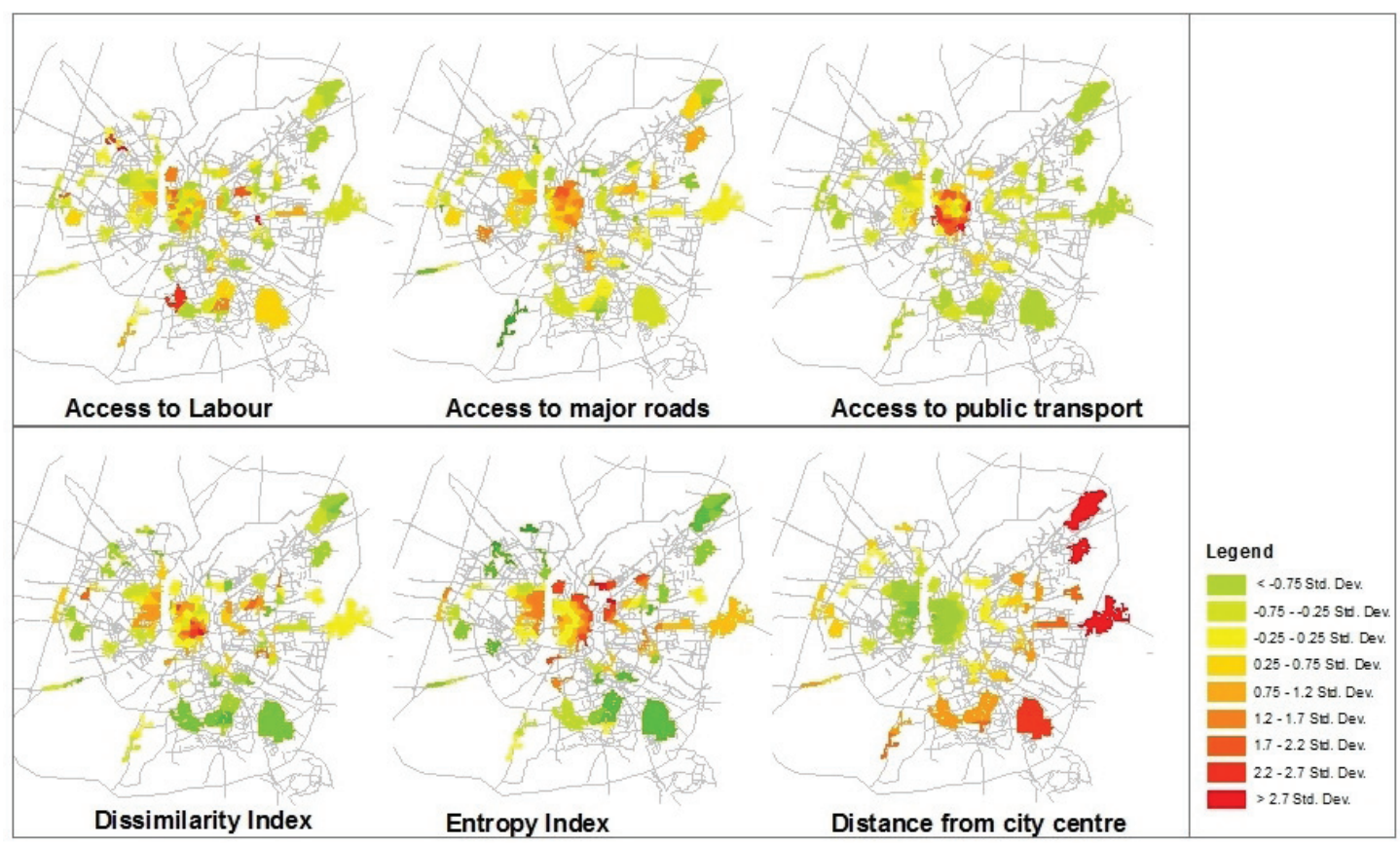

Figure 5. Access to Labour, Access to Transport and Built-form Indicators'

Source: Study Results.

Table 2. Descriptive Statistics of Access to Labour, Access to Transport and Built-form Indicators

\begin{tabular}{lrrrr}
\hline Indicator & Minimum & Maximum & Mean & Std. Deviation \\
\hline Access to labour & $\mathrm{I}$ & 100 & 8 & 12 \\
Access to major roads & 878 & 3,574 & 2,457 & $54 \mathrm{I}$ \\
Access to public transport & 3 & 646 & 137 & 124 \\
Dissimilarity Index & $0.0 \mathrm{I}$ & 0.92 & 0.39 & 0.22 \\
Entropy Index & 0.12 & 0.83 & 0.45 & 0.18 \\
Distance from city centre & 1.4 & 15.2 & 5.6 & 3.1 \\
\hline
\end{tabular}

Source: Study results.

mostly in areas where land use is mixed and diverse. The Dissimilarity Index appears to have a strong relation to activity development within employment sub-centres in central parts of the town, where as Entropy Index representing land use balance has a very strong relation with activity development in the peripheral areas of the town. Access to roads and public transport as expected have strong and significant relation with development of all employment generating activities, especially retail and commercial development. From Figure 6, one can say that the new activities develop at locations where accessibility to roads and public transport is good, and where the land use is mixed and diverse. Even the industrial areas are not exclusive nodes, retail and residential land use have also been found in the industrial area. 


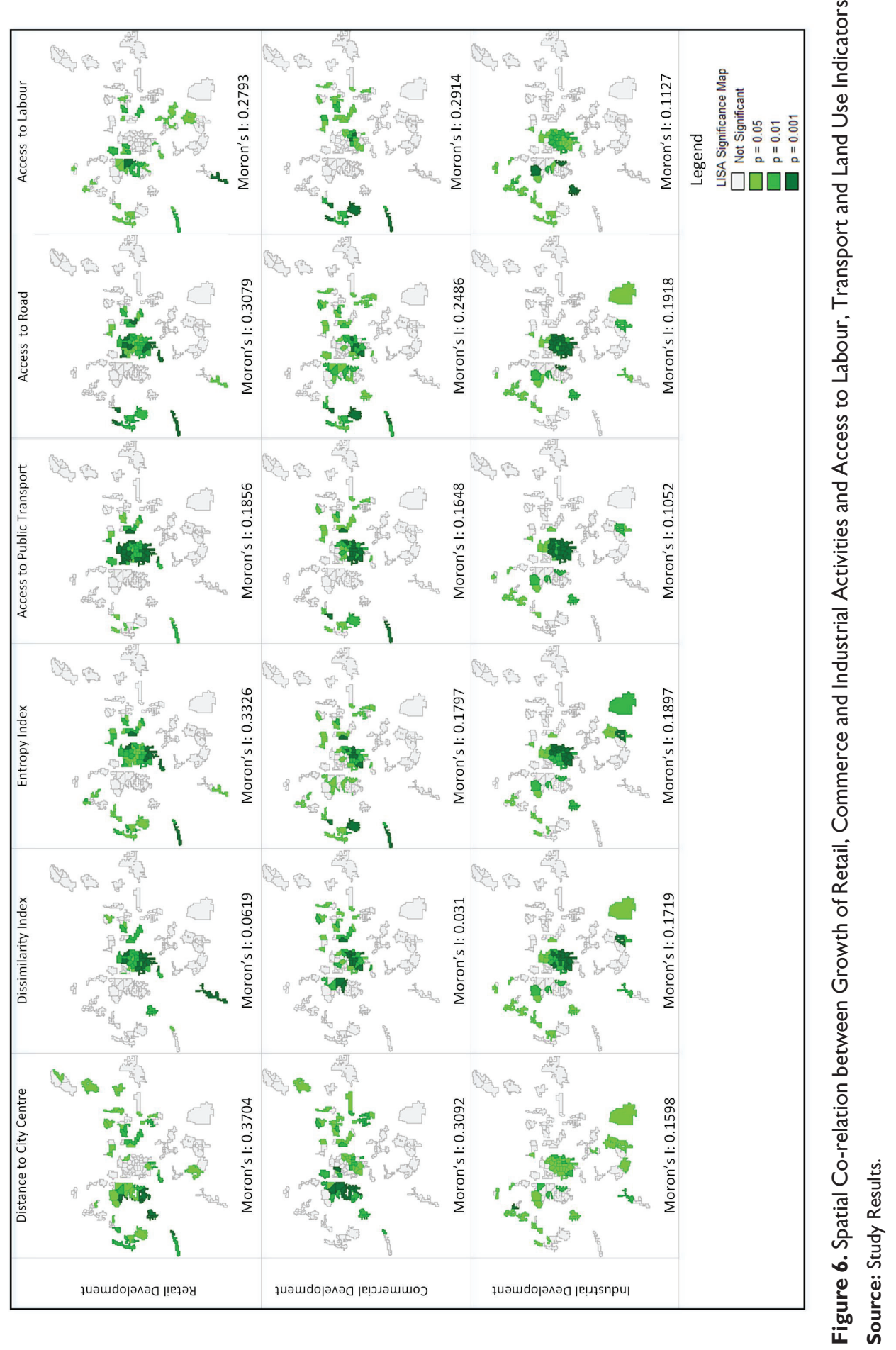


Lastly, population density has little relation with the development of activities, probably because of existing development control regulation, which restrict locations where new activities can develop and the amount of activities that can come up at a particular location.

\section{Conclusion and Discussion}

The purpose of this research was to identify employment sub-centres in the city of Ahmedabad and study the possible factors that supported the development of these employment sub-centres. This is done to gain knowledge, which can be used to support urban planning decisions in Ahmedabad and other similar cities.

The research showed that it is possible to establish suitable methods for identifying sub-centres in the context like India that has rampant unplanned growth. It is important to identify employment sub-centres, identification of existing nodes itself can help urban and transport planners to align services, for example, public transport service with these nodes. By using a cut-off employment density of 10 jobs/acre, areas that have significant employment are identified, and from these employment sub-centres could be identified by using the non-parametric method. Identification of employment also allowed analysis of the pattern of their growth and employment activities in the city. A distinct pattern of employment sub-centre formation can be observed. From the analysis of topology of employment and how employment sectors have grown, two types of agglomerations are apparent: one related to trade and commerce and the other to industry. Incidentally, in the case of Ahmedabad, these are separated by the river that divides the city in two halves. Industries are located in the eastern part and trade, commerce and the banking sector are mostly located in the western part. Accessibility has played a significant role in the formation of employment sub-centres. There has been a tendency to locate away from the CBD, that is, new firms have located at locations where there is good supply of road space and access to labour. There is also a strong co-relation with land use mix; therefore, these employment centres are not exclusive retail or commercial development because they generally develop as mixed land use along with other land uses like residential land use. The emerging patterns, spatial relations and other statistics presented in this article will help planners understand the spatial interaction between activity locations. The outputs of this article also position well in the recent debate on transit-oriented development and CBD planning. The results provided enough information for planners to make indicative judgements, of course, in the final decisionmaking for they might have to consider several other social, economic and regulatory factors also.

In this research, informal activities and their location have not been captured, which can be a significant number of jobs. If data is available on these activities, information derived can supplement the work from this research. In Ahmedabad, the BRTS system has partially changed how individual access activities, this will further change with the introduction of the newly proposed Metro system, which set up well for a follow-up research on how public transport and its use affects employment sub-centres' formation and growth.

The research did not analyse the effect of polycentric development in Ahmedabad on mode choice distances individual travel and also on spread of population. Based on past empirical work, it can be assumed, however, that the spread out, heterogeneous and dense development pattern of employment sub-centres in Ahmedabad should encourage higher use of non-motorized modes and public transport (if available). Formation of polycentric node should also have encouraged decentralization of population towards the peripheral areas, reducing/stabilizing the density in the central areas of the city. However, these are important possible ramifications which need further research. 


\section{Notes}

1. Disclaimer: This image is for representational purposes only. It may not appear well in print.

2. As Kernels are drawn for each line (road section), the function used in this study accounts for both road width and road length

3. As Kernel is drawn from each bus stop, the function used in this study accounts for both number of stop and number of bus routes.

4. Using age of the building as a proxy for age of the activity at the location does not account for change in the activity, that is, it does not indicate the age of the building and if it was used previously for some other purpose. But given the data situation in India, this was the best proxy data that could be used for the purpose.

\section{References}

Anas, A., Arnott, R., \& Small, K. A. (1998). Urban spatial structure. Journal of Economic Literature, 36, 1426-1464. Anderson, N. B., \& Bogart, W. T. (2001). The structure of sprawl: Identifying and characterizing employment centers in polycentric metropolitan areas. American Journal of Economics and Sociology, 60, 147-169.

Anselin, L., Syabri, I., \& Kho, Y. (2006). GeoDa: An introduction to spatial data analysis. Geographical Analysis, $38,5-22$.

Ballaney, S., \& Patel, B. (2008). Using the 'Development Plan-Town Planning Scheme': Mechanism to appropriate land and build urban infrastructure (India Infrastructure Report 2009, p. 190). New Delhi: Oxford University Press.

Bogart, W. T., \& Ferry, W. C. (1999). Employment centres in greater Cleveland: Evidence of evolution in a formerly monocentric city. Urban Studies, 36, 2099-2110.

Brotchie, J. F. (1984). Technology change and urban form. Environment \& Planning A, 16, 583-596.

Cervero, R., \& Kockelman, K. M. (1997). Travel demand and the 3Ds: Density, diversity, and design. Transportation Research Part D: Transport and Environment, 2, 199-219.

Chattopadhyay, S. (2017). Neoliberal urban transformations in Indian cities: Paradoxes and predicaments. Progress in Development Studies. DOI: 10.1177/1464993417716355

Christaller, W. (1966). Central places in southern Germany (C. W. Baskin, trans.). Englewood Cliffs, NJ: Prentice-Hall.

Craig, S. G., \& NG, P. T. (2001). Using quantile smoothing splines to identify employment subcenters in a multicentric urban area. Journal of Urban Economics, 49, 100-120.

Fujita, M., Krugman, P., \& Venables, A. J. (2001). The spatial economy: Cities, regions, and international trade. Cambridge, MA: The MIT Press.

Giuliano, G., Redfearn, C., Agarwal, A., \& He, S. (2012). Network accessibility and employment centres. Urban Studies, 49, 77-95.

Giuliano, G., \& Small, K. A. (1991). Subcenters in the Los Angeles region. Regional Science and Urban Economics, $21,163-182$.

- (1999). The determinants of growth of employment subcenters. Journal of Transport Geography, 7(3), 189-201.

Hall, P. G., \& Pain, K. (2006). The polycentric metropolis. London and Sterling, VA: Earthscan.

Hotelling, H. (1929). Stability in competition. The Economic Journal, 39, 41-57.

Ilhamdaniah, Munshi, T., \& Amer, S. (2005). Evaluating the planning for social infrastructure in Ahmedabad city, India. Paper presented at the 2005 Conference on Computers in Urban Planning and Urban Management (CUPUM), UCL, London.

Kloosterman, R. C., \& Lambregts, B. (2001). Clustering of economic activities in polycentric urban regions: The case of the Randstad. Urban Studies, 38, 717-732.

Mahadevia, D. (2001). Sustainable urban development in India: An inclusive perspective. Development in Practice, $11,242-259$.

McMillen, D. P. (2001). Nonparametric employment subcenter identification. Journal of Urban Economics, 50, 448-473. 
McMillen, D. P., \& McDonald, J. F. (1997). A nonparametric analysis of employment density in a polycentric city. Journal of Regional Science, 37, 591-612.

McMillen, D. P., \& Smith, S. C. (2003). The number of subcenters in large urban areas. Journal of Urban Economics, $53,321-338$.

Meijers, E. (2005). Polycentric urban regions and the quest for synergy: Is a network of cities more than the sum of the parts? Urban Studies, 42, 765-781.

Muniz, I., Galindo, A., \& Garcia, M. A. (2003). Cubic spline population density functions and satellite city delimitation: The case of Barcelona. Urban Studies, 40, 1303-1321.

Munshi, T. (2003). Planning public transport of Ahmedabad City in India (Unpublished Masters Thesis). The Netherlands: ITC.

- (2013). Built form, travel behaviour and low carbon development in Ahmedabad, India (PhD thesis). The Netherlands: University of Twente.

- (2016). Built environment and mode choice relationship for commute travel in the city of Rajkot, India. Transportation research part D: Transport and environment, 44, 239-253.

Munshi, T., Belal, W., \& Dijst, M. (2004). Public transport provision in Ahmedabad, India: Accessibility to work place. In L. C. Wadhwa (Ed.), Urban transport X: Urban transport and the environment in the 21st century (pp. 343-353). Southampton: WIT Press.

Munshi, T., Shah, K., Vaid, A., Sharma, V., Joy, K., Roy, S. ... Joseph, Y. (2014a). Low carbon comprehensive mobility plan, Rajkot (Unpublished Report). Roskilde: UNEP Risoe Centre on Energy, Climate and Sustainable Development, Technical University of Denmark.

Munshi, T., Zuidgeest, M., Brussel, M., \& Van Maarseveen, M. (2014b). Logistic regression and cellular automatabased modelling of retail, commercial and residential development in the city of Ahmedabad, India. Cities, 39, 68-86.

Porter, M. E. (2000). Locations, clusters, and company strategy. In Gordon L Clark, Meric S. Gertler \& Maryann P. Feldman (Eds), The Oxford handbook of economic geography (pp. 253-274). Oxford: Oxford University Press.

Redfearn, C. L. (2007). The topography of metropolitan employment: Identifying centers of employment in a polycentric urban area. Journal of Urban Economics, 61(3), 519-541.

Richardson, H. (1980). Polarization reversal in developing countries. Papers in Regional Science, 45, 67-85.

Romein, A., Verkoren, O., \& Fernandez, A. M. (2009). Polycentric metropolitan form: Application of a 'northern' concept in Latin America. Footprint, 3, 127-146.

Roy, A. (2009). Why India cannot plan its cities: Informality, insurgence and the idiom of urbanization. Planning Theory, 8, 76-87.

Shearmur, R. G., \& Coffey, W. J. (2002). Urban employment subcenters and sectoral clustering in Montreal: Complementary approaches to the study of urban form. Urban Geography, 23, 103-130.

Small, K. A., \& Song, S. F. (1994). Population and employment densities, structure and change. Journal of Urban Economics, 36, 292-313.

Stantchev, D., \& Merat, N. (2010). Thematic Research Summary: Equity and Accessibility. Transport Research Knowledge Centre, European Commission.

Tracy, A. J., Su, P., Sadek, A. W., \& Wang, Q. (2011). Assessing the impact of the built environment on travel behavior: A case study of Buffalo, New York. Transportation, 38, 663-678. 